\title{
Averrhoa bilimbi ingestion and acute kidney injury: A case series \\ Madhura $\mathrm{AR}^{1, *}$ and Jayaraj $\mathbf{P M}^{2}$ \\ ${ }^{1}$ Department of General Medicine, Mother Hospital, Thrissur, Kerala-680012, India \\ ${ }^{2}$ Department of Nephrology, Mother Hospital, Thrissur, Kerala-680012, India
}

\begin{abstract}
Averrhoa bilimbi (Irumban puli) is commonly used in South India for variety of household preparations and also as a remedy for hypertension, diabetes and dyslipidemia. The fruit has very high oxalate content which, when consumed in large quantities, forms calcium oxalate crystals in the renal tubules. These crystals get adhered to the tubular cells and cause cell necrosis resulting in acute kidney injury. We describe a series of 4 such cases who presented to us in acute renal failure after consumption of Averrhoa bilimbi in excess. 3 out of 4 patients required hemodialysis. There was recovery of renal function at the end of 2-6 weeks.
\end{abstract}

Keywords: Averrhoa bilimbi; irumban puli; oxalate crystals; acute tubular necrosis; AKI

*Corresponding author: Dr. Madhura AR, Senior Resident, Department of General Medicine, Mother Hospital, Thrissur, Kerala-680012, India. Mobile: 09611847280; Email: madhura140@gmail.com

Received 10 September 2020; Revised 25 November 2020; Accepted 11 December 2020; Published 19 December 2020

Citation: Madhura AR, Jayaraj PM. Averrhoa bilimbi ingestion and acute kidney injury: A case series. J Med Sci Res. 2021; 9(1):4549. DOI: http://dx.doi.org/10.17727/JMSR.2021/9-8

Copyright: (C) 2021 Madhura AR et al. Published by KIMS Foundation and Research Center. This is an open-access article distributed under the terms of the Creative Commons Attribution License, which permits unrestricted use, distribution, and reproduction in any medium, provided the original author and source are credited.

\section{Introduction}

Averrhoa bilimbi is one of the important medicinal plants of many tropical and subtropical countries of the world. Averrhoa bilimbi is closely related to Averrhoa carambola (starfruit). It is cultivated throughout Malaysia, Indonesia, Singapore, Philippines, Thailand, Bangladesh, Myanmar, and India [1]. The fruits of the tree are greenish in colour with a firm and juicy flesh which becomes soft on ripening. The fruit juice is sour and extremely acidic [2]. The fruit is rich in vitamin $\mathrm{C}$ and oxalic acid [3]. It is known to cause acute kidney injury (AKI) due to calcium oxalate crystal deposition in renal tubules, acute tubular necrosis, acute interstitial nephritis and chronically may cause interstitial fibrosis [4]. We describe a series of four cases who presented to us with AKI after consumption of Averrhoa bilimbi (also called Irumban puli). 


\section{Case series}

\section{Case 1}

A 34-year-old male presented with complaints of swelling of both lower limbs, abdominal distension and facial puffiness of 3 days duration. He also had decreased urine output over last 2 days, but no history of hematuria or abdominal pain. He reported nausea, but there were no episodes of vomiting or loose stools. No history of any co-morbidities or hospital admissions till the present visit. He had consumed about $500 \mathrm{ml}$ of wine prepared from Averrhoa bilimbi 5 days earlier at his house. On examination, his pulse rate: $85 / \mathrm{min}$ and regular, BP: $170 / 100 \mathrm{~mm} \mathrm{Hg}$, afebrile, respiratory rate (RR): $24 / \mathrm{min}$. There was bilateral pitting pedal edema extending upto two-thirds of both the legs, periorbital puffiness and evidence of free fluid in the abdomen. Investigations revealed severe AKI with serum creatinine: $9.8 \mathrm{mg} / \mathrm{dl}$, with normal hemogram and liver function tests. Urine microscopy showed trace proteinuria, 3-4 WBCs and plenty of oxalate crytals. Ultrasound abdomen showed normal sized kidneys with well maintained cortico-medullary differentiation (CMD). No evidence of calculi/ hydronephrosis. ABG showed partially compensated metabolic acidosis. He was started on furosemide and nitroglycerin IV infusion. However, in view of persistent oliguria, fluid overload and acidosis, he was started on hemodialysis. Symptoms improved after 2 sessions following which a left percutaneous kidney biopsy was done which showed acute tubular necrosis with intra-tubular calcium oxalate crystals (Figure 1). He required about 8 hemodialysis sessions. His renal function tests returned to normal $(1.3 \mathrm{mg} / \mathrm{dl})$ in 6 weeks.

\section{Case 2}

A 48-year-old male, with history of type 2 diabetes mellitus and dyslipidemia on medications presented with excessive fatigue, nausea, loss of appetite and vomiting for the last 1 week. There was no history of fever/ abdominal pain/ loose stools/ decreased urine output. He gave history of consumption of Averrhoa bilimbi fruit juice for about 5 days to control the serum cholesterol levels, one week prior to the visit to our centre. On examination, he was afebrile, BP was 140/90 mm Hg, RR: 18/min. He had normal complete hemogram, serum creatinine: 8.5 $\mathrm{mg} / \mathrm{dl}$, normal liver function tests, total cholesterol: $240 \mathrm{mg} / \mathrm{dl}$, LDL: $145 \mathrm{mg} / \mathrm{dl}, \mathrm{HbA1c}$ : 7.1\% and urine microscopy showed 1+ proteinuria with plenty of oxalate crystals (Figure 2). Ultrasound abdomen showed slightly bulky kidneys but CMD was well maintained. He underwent left percutaneous kidney biopsy which showed acute tubular necrosis with many polarizable fractured crystals in the tubular lumina (calcium oxalate crystals). He was initiated on hemodialysis. He improved symptomatically with time. Around 6 sessions of hemodialysis were done and his serum creatinine returned to baseline of 1.2 $\mathrm{mg} / \mathrm{dl}$ at the end of 4 weeks.

\section{Case 3}

A 39-year-old male presented with nausea, vomiting and excessive fatigue for the last 2 days. No fever or abdominal pain or dysuria. He had no other significant co-morbidities. He gave history of consumption of about $250 \mathrm{ml}$ of wine made of Averrhoa bilimbi fruit 4 days before the visit. On examination, he was afebrile, no edema, BP was $130 / 80 \mathrm{mmHg}$, RR was $16 / \mathrm{min}$. Serum creatinine was $5.6 \mathrm{mg} / \mathrm{dl}$. Urine microscopy showed plenty of oxalate crystals. Ultrasound abdomen was normal. Patient was managed conservatively with fluid management. Kidney biopsy and hemodialysis were not carried out in view of symptomatic improvement of patient. His renal function returned to normal (Serum creatinine: $0.8 \mathrm{mg} / \mathrm{dl}$ ) at the end of 2 weeks.

\section{Case 4}

A 42-year-old male presented with swelling of both lower limbs and abdominal distension for last 5 days, decreased urine output for 2 days and breathlessness of 1 day duration. No history of fever, vomiting, pain abdomen, chest discomfort or alcohol intake. No significant co-morbidities. He had returned from abroad 15 days back and had consumed Averrhoa bilimbi fruit juice of about $200 \mathrm{ml}$ every day, for about 4-5 days. On examination, Pulse was 102/ min, BP was $220 / 110 \mathrm{~mm} \mathrm{Hg}$, RR was $35 / \mathrm{min}$, sp02 was $90 \%$ on room air. He had bilateral pitting pedal edema, bilateral basal crepitations and evidence of free fluid in the abdomen. Investigations showed severe renal failure with serum creatinine: $12.5 \mathrm{mg} /$ $\mathrm{dl}$, normal hemogram, slightly elevated liver enzymes and plenty of oxalate crystals in urine microscopy. Bedside ultrasound showed normal sized kidneys without any evidence of calculi/hydronephrosis. In view of oliguria, accelerated hypertension and acute pulmonary edema, he was initiated on 
hemodialysis. Kidney biopsy was deferred in view of poor general condition of the patient. However, he showed symptomatic improvement after 2-3 sessions of hemodialysis, urine output slowly improved, chest congestion was relieved and edema started subsiding. He required about 12 sessions of hemodialysis. Serum creatinine at the end of 6 weeks was $2.3 \mathrm{mg} / \mathrm{dl}$ and he was advised regular nephrology follow-up.

Table 1: Clinical and demographic details of patients who presented with AKI.

\begin{tabular}{|c|c|c|c|c|}
\hline Parameters & Case 1 & Case 2 & Case 3 & Case 4 \\
\hline Age (years) & 34 & 48 & 39 & 42 \\
\hline Sex & M & M & M & M \\
\hline Co-morbities & None & DM, DLP & None & None \\
\hline $\mathrm{BP}(\mathrm{mm} \mathrm{Hg})$ & $170 / 100$ & $140 / 90$ & $130 / 80$ & $220 / 110$ \\
\hline Edema & ++ & - & - & ++ \\
\hline Oliguria & + & - & - & + \\
\hline Urine protein & Trace & $1+$ & - & Trace \\
\hline Urine WBCs & $3-4 / \mathrm{HPF}$ & 2-3/HPF & $0-1 / \mathrm{HPF}$ & 3-4/HPF \\
\hline Urine RBCs & $0-1 / \mathrm{HPF}$ & $0-2 / \mathrm{HPF}$ & $0-1 / \mathrm{HPF}$ & 1-2/HPF \\
\hline Urinary calcium oxalate crystals & Plenty & Plenty & Plenty & Plenty \\
\hline Highest serum creatinine $(\mathrm{mg} / \mathrm{dl})$ & 9.8 & 8.5 & 5.6 & 12.5 \\
\hline USG abdomen & Normal & Slightly bulky kidneys & Normal & Normal \\
\hline Kidney biopsy & $\begin{array}{l}\text { ATN with intra-tubular } \\
\text { oxalate crystals }\end{array}$ & $\begin{array}{l}\text { ATN with intra-tubular } \\
\text { oxalate crystals }\end{array}$ & Not done & Not done \\
\hline Hemodialysis done & Yes & Yes & No & Yes \\
\hline Recovery time & 6 weeks & 4 weeks & 2 weeks & 6 weeks \\
\hline Lowest serum creatinine (mg/dl) & 1.3 & 1.2 & 0.8 & 2.3 \\
\hline
\end{tabular}

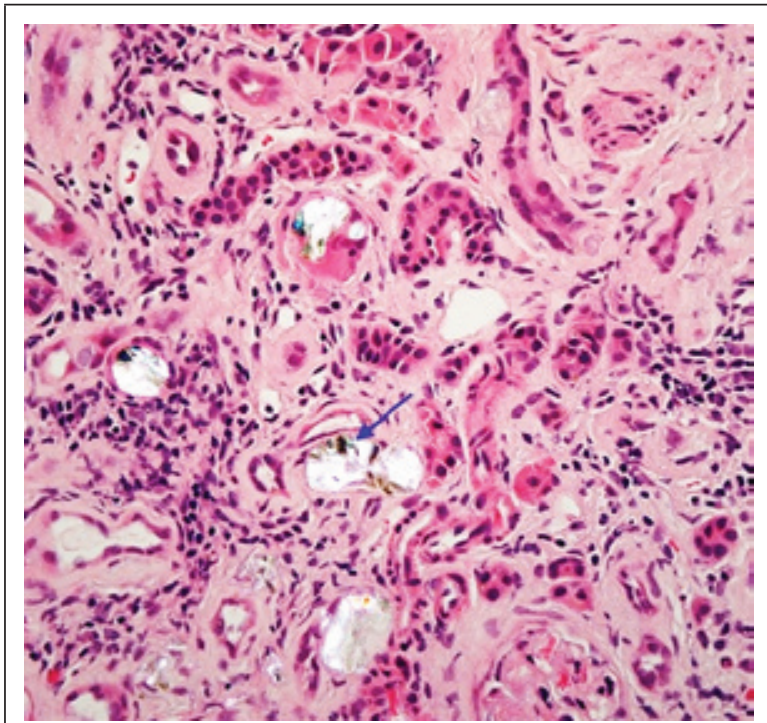

Figure 1: Renal tubules showing features of acute tubular necrosis with fractured crystals in the lumen.

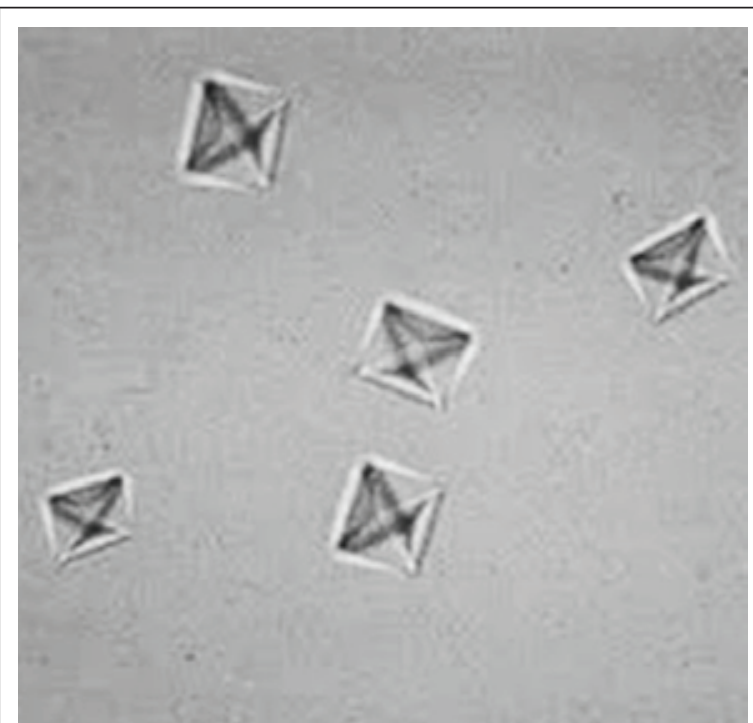

Figure 2: Urine microscopy showing calcium oxalate crystals (Envelope shaped). 


\section{Discussion}

Averrhoa bilimbi of the family, oxalidaceae is a small tree 5-10 meters high. Fruits are fairly cylindrical with five broad rounded longitudinal lobes and produced in clusters. Bilimbi fruits are very sour and are commonly used in the production of vinegar, wine, and pickles. Averrhoa bilimbi is used for the treatment of hyperlipidemia, hypertension, and diabetes by different communities [5, 6]. This fruit is very rich in oxalate content: $25.1 \mathrm{mg} / 100 \mathrm{~g}$ compared to other fruits like cranberry $(1.1 \mathrm{mg} / 100 \mathrm{~g})$, grape $(1.6 \mathrm{mg} / 100 \mathrm{~g})$, tomato $(5.5 \mathrm{mg} / 100 \mathrm{~g})$, pineapple $(7.3 \mathrm{mg} / 100 \mathrm{~g})$, orange $(2.2 \mathrm{mg} / 100 \mathrm{~g})$, apple $(0.5$ $\mathrm{mg} / 100 \mathrm{~g}$ ), banana $(3.2 \mathrm{mg} / 100 \mathrm{~g}$ ) [7]. Excessive ingestion of this fruit in any form, results in secondary hyperoxaluria.

Primary hyperoxaluria is a rare inborn error of glyoxylate metabolism characterized by the overproduction of oxalate, which deposits as calcium oxalate in various organs as kidney function declines. Secondary hyperoxaluria is more common and is usually the result of increased dietary oxalate intake, increased intestinal oxalate availability, decreased intestinal oxalate degradation, or increased colonic permeability to oxalate. Excessive dietary consumption accounts for $30.6 \%$ cases of secondary oxalate nephropathy [8].

The initial event in the development of oxalate nephropathy is the formation of calcium oxalate crystals in the lumen of proximal tubules followed by adhesion of calcium oxalate crystals to the surface of tubular epithelial cells. Calcium oxalate binding proteins that promote oxalate nephropathy have also been identified [9]. Inflammasomes represent large multimolecular cytosolic complexes that assemble into a platform for the activation of pro-inflammatory caspase-1. Inflammasomes are important mediators of apoptosis, interstitial inflammation and fibrosis in various types of renal disease. Of great importance in the context of oxalate nephropathy is the nucleotidebinding domain, leucine-rich repeat inflammasome (NALP3 or NLRP3). When activated, NALP3 proteins oligomerize and form a protein complex with caspase- 1 . This process activates caspase- 1 which cleaves the inactive precursors of IL-1 $\beta$ and IL-18 to generate active cytokines that promote interstitial inflammation and fibrosis, as well as progression of renal failure, in oxalate nephropathy [10, 11]. Extensive tubular damage with epithelial necrosis and dilatation of tubular lumen is the cardinal characteristic of oxalate nephropathy. Crystal deposition can also occur in walls of the renal vessels, while the involvement of glomeruli is inconsistent.

In our case series, all the patients had history of excessive dietary consumption of A.bilimbi resulting in AKI. Envelope-shaped calcium oxalate crystals were demonstrated in urine microscopy of all the patients. 2 patients underwent percutaneous kidney biopsy which showed acute tubular necrosis with many polarizable fractured oxalate crystals in the tubular lumina. 3 out of 4 patients underwent hemodialysis. Renal function recovered in all 4 patients over 2-6 weeks.

\section{Conclusion}

Averrhoa bilimbi (Irumban puli) is used as an ingredient in fruit juice, wine and pickles in South India. It is also traditionally used as a remedy for ailments like hyperlipidemia, hypertension and diabetes. When consumed in excess, it can lead to AKI secondary to acute tubular necrosis, due to its high oxalate content. Therefore, we recommend not to consume oxalate-rich food in excess, which may cause life threatening consequences.

\section{Conflicts of interest}

Authors declare no conflicts of interest.

\section{References}

[1] Alhassan AM, Ahmed QU. Averrhoa bilimbi Linn: A review of its ethnomedicinal uses, phytochemistry, and pharmacology. J Pharm Bioallied Sci. 2016; 8(4):265-271.

[2] De Lima VL, Mélo ED, Lima LD. Physicochemical characteristics of bilimbi (Averrhoa bilimbi L.) Rev Bras Frutic. 2011; 23(2):421-423.

[3] Hasanuzzaman M, Ali MR, Hossain M, Kuri S, Islam MS. Evaluation of total phenolic content, free radical scavenging activity and phytochemical screening of different extracts of Averrhoa bilimbi (fruits). Int Curr Pharm J. 2013; 2(4):9296.

[4] Men LC, Chang E. Acute kidney injury secondary to Averrhoa bilimbi ingestion. Kidney International Reports. 2017; 2(4):S1-S41.

[5] Pushparaj P, Tan CH, Tan BK. Effects of Averrhoa bilimbi leaf extract on blood glucose and lipids in streptozotocindiabetic rats. Journal of Ethnopharmacology. 2000; 72(12):69-76.

[6] Ambili S, Subramoniam A, Nagarajan NS. Studies on the antihyperlipidemic properties of Averrhoa bilimbi fruit in rats. Planta Medica. 2009; 75(1):55-58.

[7] Bakul G, Unni VN, Seethaleksmy NV, Mathew A, Rajesh R, et al. Acute oxalate nephropathy due to Averrhoa bilimbi fruit juice ingestion. Indian J Nephrol. 2013; 23(4):297-300. 
[8] Lumlertgul N, Siribamrungwong M, Jaber BL, Susantitaphong P. Secondary oxalate nephropathy: A systematic review. Kidney Int Rep. 2018; 3(6):1363-1372.

[9] Glew RH, Sun Y, Horowitz BL, Konstantinov KN, Barry M, et al. Nephropathy in dietary hyperoxaluria: A potentially preventable acute or chronic kidney disease. World J Nephrol 2014; 3(4):122-142.

[10] Kurts C. A crystal-clear mechanism of chronic kidney disease. Kidney Int. 2013; 84(5):859-861.

[11] Mulay SR, Kulkarni OP, Rupanagudi KV, Migliorini A, Darisipudi MN, et al. Calcium oxalate crystals induce renal inflammation by NLRP3-mediated IL-1 $\beta$ secretion. J Clin Invest. 2013; 123(1):236-246. 